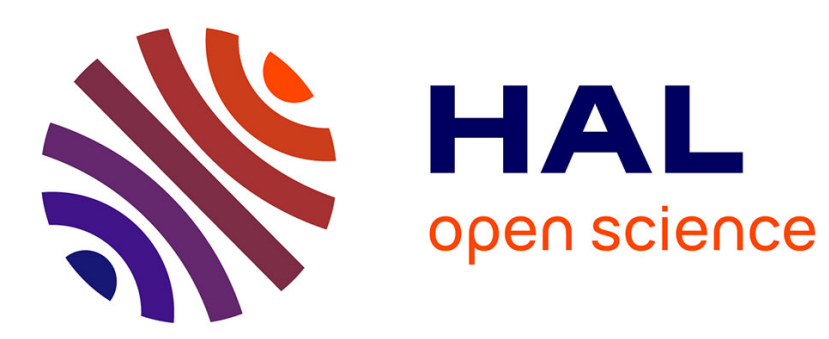

\title{
Acquisition and circulation of flint materials in the Linear Pottery Culture of the Seine Basin
}

Pierre Allard

\section{To cite this version:}

Pierre Allard. Acquisition and circulation of flint materials in the Linear Pottery Culture of the Seine Basin. Between History and Archaeology: Papers in honour of Jacek Lech, pp.165-172, 2018. halshs-03334614

\section{HAL Id: halshs-03334614 https://shs.hal.science/halshs-03334614}

Submitted on 4 Sep 2021

HAL is a multi-disciplinary open access archive for the deposit and dissemination of scientific research documents, whether they are published or not. The documents may come from teaching and research institutions in France or abroad, or from public or private research centers.
L'archive ouverte pluridisciplinaire HAL, est destinée au dépôt et à la diffusion de documents scientifiques de niveau recherche, publiés ou non, émanant des établissements d'enseignement et de recherche français ou étrangers, des laboratoires publics ou privés. 


\title{
Acquisition and circulation of flint materials in the Linear Pottery Culture of the Seine
}

\section{Basin}

Pierre ALLARD

CNRS, UMR 7055 Préhistoire and Technologie

Maison de l'Archélogie et de l'Ethnologie

21 Allée de l’Université

92023 Nanterre Cedex, France

pierre.allard@mae.u-paris10.fr

\begin{abstract}
This paper proposes a synthesis of recent discoveries and their implications for our knowledge of the Danubian lithic territory of acquisition and the circulation networks. With the recent discoveries it is really possible to talk in terms of networks in so far as the various links are now known for the Danubian period - from the flint's extraction site to its sites of production and consumption. These networks played a part in the functions of the society of the Linear culture and the relationships of which they are the sign are complex. There is no correlation between the distance from the sources and the intensity of the circulations
\end{abstract}

Keywords : Early Neolithic, flint, raw material, flint network, LinearBandCeramic 


\section{Introduction}

Thanks to preventive archaeology since the 1990 s the data available concerning the lithic industry of the Early Neolithic in the North of France have become a good deal more substantial. At present, more than 200 sites can be attributed to the Danubian Neolithic and the chronology of this period is divided in two with the succession of the Linear Pottery Culture (Rubané in french) and Blicquy/Villeneuve-Saint-Germain (BQ/VSG) cultures, i.e. $5300-4750$ BC.

This article proposes a synthesis of recent discoveries and their implications for our knowledge of the Danubian lithic industries and will give special emphasis to the evolution of the territory of acquisition and the circulation networks for flint in the Early Neolithic in the Paris Basin.

\section{The Seine Basin Linear Pottery Culture}

The documentation for LPC sites depends on a few well-known (or rather better-known) sectors thanks to major systematic surveillance programmes in the valleys of the Aisne, Oise, and Yonne or Marne. Elsewhere new discoveries have been invaluable indicators for assessing gaps in the evidence and conducting surveys concerning the implantation of Linear culture in the Paris Basin. For example, the implantation of the sites of Colombelles and Démouville (Billard et al. 2014; Saint Allain 2010) at the edge of the Manche proves that the populations of the Early Neolithic settled the western part of the Paris Basin and reached the shores of the Manche as early as the Linear. As concerns the Villeneuve-Saint-Germain / 
Blicquy occupation density is higher and not only includes the main valleys but also the secondary valleys and above all the plateaus' edges. The expansion westwards up to the outskirts of the Armorican massif is broadly attested (Marchand et al. 2006).

The chronological framework is now established to the extent that most of the recent research on the material culture shows the evident succession and descent of the Linear and subsequent Blicquy/Villeneuve-Saint-Germain cultures. The only important modification concerns a homogenisation of the periodisation in the North France Early Neolithic following numerous works on the ceramic serialisations of various regions (Lefranc 2007; Blouet et al., 2013; Meunier 2012). Thus, the Paris Basin LPC has been replaced by the "Seine Basin Rubané" (Ilett and Meunier 2013) and is organised as follows: Middle Seine basin Rubané (instead of Middle Champagne Rubané), Late Seine Basin Rubané (instead of Late Champagne Rubané), and lastly Final Seine Basin Rubané (instead of Late Paris Basin Rubané (RRBP- Rubané récent $d u$ Bassin parisien) - final phase included). The dates for the whole North France Rubané sequence are included between 5300-4950 cal BC.

The Linear lithic industry in the north-east of France has been the subject of several regional syntheses since the pioneering work of JP Farruggia (1971). The multiplicity of discoveries from Linear sites in the valleys of the Aisne, the Marne (in the Perthois), the Seine-Yonne confluence and Alsace have led to studies on the lithic finds enabling the features of the Danubian lithic industry to be fixed in its broad outlines (Plateaux 1986, 1990; Tappret and Villes 1996; Mauvilly 1997; Augereau 2004). A global survey of the whole region concerned has been conducted which has made it possible to propose the first general synthesis for the terminal expansion area of the European Linear Ceramic (Allard 2005). 
When we made our first synthesis (Allard 2005) two regions - Yonne and the Aisne valley - offered satisfying conditions for research, i.e. numerous sites with substantial lithic corpora. Now, the discovery of new large lithic assemblages in Champagne at Bréviandes (Laurelut 2010), Saint Martin des Près (Garmond et al., 2013), or again Pont-sur-Seine (Fournand et al. 2010), as also in Normandy (Billard et al., 2014) or again in the Yonne at Etigny le Brassot (Augereau et al., 2006) provide a complete overview of the Linear lithic industries in the North of France and more particularly of its evolution in the Seine Basin. The transition with the Blicquy/Villeneuve Saint Germain group is also well documented with the recent discoveries of Saint Pierre d'Autils in Haute-Normandie (Prost et al. 2012), Sours les Ouches (Dupont et al. 2010), or again of Moneteau in the Yonne (Augereau et al. 2011 ).

In the LPC industry of north-east France the laminar blanks were privileged (Constantin 1985; Plateaux 1986; Mauvilly 1997; Allard 2005). A real debitage economy existed that integrated the whole of blade knapping waste (Allard 2005). Thus flake toolmaking is still present, but in proportions varying greatly from one site to another. In the sector of the Seine-Yonne confluence all the series deliver assemblages in which the tools made off flakes are preponderant (Augereau 2004). The typology of the lithic tools from the Linear in the Paris Basin underlines the obvious relationship between all the Linear lithic industries in western Europe (Cahen et al. 1986; Plateau 1986; Mauvilly 1997; Allard 2005). The tools made off blades are the hallmark of the cultural typological unity of all the sites. The composition of the assemblages is stereotyped - being generally limited to a few categories of types by region (without taking the blanks into account). The end scrapers, the fittings for arrows and sickles, awls, and retouched blades and flakes make up the common pool. Moreover, the Paris Basin presents several regional particularities such as the abundance of splintered pieces (a point in common with Alsace and Lorraine) or the 
recurrent presence of toothed blades. The burins distinguish above all the Paris Basin series as this tool is practically non-existent in the other zones where the Linear was implanted (Plateaux 1982). The chronological evolution is perceptible, for the end of the Seine Linear is marked by evidence of flake debitage. This debitage becomes preponderant in the Blicquy/Villeneuve-Saint-Germain (Bostyn 1994).

\section{The supplying territory}

In the Linear the flint resources exploited were very often diversified and quite important variations are observed between the sites or the dwelling units in the settlements. In spite of the apparent diversity of materials the blades were knapped off good quality flints. This selection was often oriented towards regional materials sometimes far from the settlements rather than varieties of flint available locally but of lesser quality. This observation explains the regional situations found in the Paris Basin or more generally in western Europe.

- Thus in the Seine-Yonne sector the sites are found in alluvial valleys that cross a geological landscape in which flint resources are plentiful and easily accessible whether in primary position or secondary (in the upper Cretaceous levels, Mauger 1985). The lithic series are rich and the local Cretaceous flint was used. A second variety described as finegrained flint was used for blade knapping and the tertiary flint is occasional (Augereau 2004). An analogous situation is observed in the series of Linear sites in the Oise Basin (Pont-Sainte-Maxence et Chambly, Alix et al. 1997; Boucneau et al. 1996); the course of the Oise also runs through upper Cretaceous chalk basin which yields large quantities of flints in this sector. 
- The lithic series from the LPC sites of the Aisne, Champagne and Normandy, on the other hand, show a wide variety of exploited flints.

In the Aisne valley an evident preference for quality existed in favour of the use of blond Senonian flints for blade knapping. The nearest deposits are at about 30-50 km from the settlements. They are in principle located in the Marne and the cores arrived already prepared. Generally in the minority in the inventories it is over-represented among the blades and the tools made from blades (Allard 2003). The Tertiary Bartonian flint is over 20 $\mathrm{km}$ from the settlements for the known deposits. Lastly, the Turonian formations emerge in primary position $15-20 \mathrm{~km}$ away also, but these flints are also abundant in the alluviums. They were but little exploited except for the eastern sector: in the Commune of Berry-auBac a real "frontier" existed where the use of this flint became predominant and then almost exclusive at the sites of Berry-au-Bac "la Croix Maigret" and Menneville "Derrière-leVillage" (Plateaux 1990; Allard 2005). In this way, the procurement territory for the materials is wide and varied and above all oriented towards regional flints (15 to $50 \mathrm{~km}$ ).

In Champagne the situation is similar to that of the Aisne valley. The main outcrops are located in the west and south-west of the Department along the Tertiary cuesta. Two varieties of Senonian flint are exploited representing $80 \%$ of the material at Juvigny, Orconte, and Écriennes and $56 \%$ at Saint-Dizier. The distribution of these two varieties differs between Juvigny and the settlements in the plain of Perthois. The flints' origins are 10 to $15 \mathrm{~km}$ away for Juvigny and $20-30 \mathrm{~km}$ for the second variety in relation to the Perthois sites. The tertiary flint - probably Bartonian - is present in all the settlements but is rare in the Perthois (a few pieces) and not very abundant at Juvigny (7. $2 \%$ ) as at Saint-Martin sur le Pré (Garmond et al. 2012). The tertiary flints in the settlements of the Perthois are considered to be exogenous products as they are only blades or tools (Allard 2005). 
Poor quality flints, frost-shattered stones, and quartz pebbles complete the spectra of the materials for each series. The quartz is knapped following non-blade patterns, in principle for use as a splintered piece (especially in comparison with what is found in Alsace according to Mauvilly 1997). Just like the settlements in the Aisne valley these materials are in a minority in the assemblages.

The discovery of Bréviandes in the region of Troyes (Laurelut 2010; Allard unpublished), presents a range of materials oriented towards neighbouring flints, between 5 and $10 \mathrm{~km}$ from the sites. Only one piece in Bartonian flint is present (a fitting for an arrow).

In Normandy the analyses of the lithic industry of the site of Colombelles (Billard et al. 2014) provide evidence of highly diversified procurement of raw materials. While the regional materials (flint from the Cinglais and grey-blue granular flint of unknown origin) are very much in the majority ( $93 \%$ ), flint of secondary origin of which the nearest outcrops are over $25 \mathrm{~km}$ from the site were also brought to the site in a form already prepared.

Lastly, in the Moselle valley and Basse-Alsace, that is to say in the regions touching the Paris Basin, very high quality flints are globally absent. Nevertheless, lithic resources of variable quality - sometimes good such as the Oxfordian from the Commercy-Saint Mihiel region - are listed in Lorraine (Blouet 2005). However, the Linear settlements yield sparse series essentially comprising blades and tools made off blades from flints from outside the Rhine-Meuse region and the Paris Basin (Champagne Senonian and Tertiary, Blouet 2005). In Basse-Alsace the situation is similar, but the series seem even poorer and the Neolithic knappers used various local lithic materials especially for non-blade productions (Mauvilly 2000). As for Haute-Alsace, it shows a situation similar to the Paris Basin with a mixed supply of regional materials and exogenous Senonian and Tertiary flints from the Paris Basin. 


\section{The circulations of flints}

Very early on, Polish researchers developed the issue of acquisition and methods of procurement in the study of the Linear lithic industry (for example, the synthesis of Kaczanowska and Lech 1977), which have resulted in several exhaustive syntheses that found the bases of the issue of the circulation networks for flint products in central Europe (Lech 1980, 1987, 1990). For J. Lech the circulations are synonyms of exchanges and consist of two types of networks. The first is essentially economic, as the technological study of the flints shows the existence of various links in the chain along which the flint materials were disseminated: from the extraction sites, through production and distribution to consumption. Certain exchanges turn out to be of a quite different nature and are manifested by the presence of a few exogenous objects on the sites in environments with abundant raw materials. This is the case, for instance, of the few obsidian objects at CracowOlszanica. These rare objects were socially significant and affirmed the ties or contacts with the neighbouring zones. The research studies on the lithic finds from the Polish Linear sites are the starting point for the ensuing discussions in this chapter.

There is plenty of evidence for the circulation of flints in the Paris Basin and all the zones of settlement known were connected together. They are also of two types just as $\mathrm{J}$ Lech describes for central Europe.

- These circulations may have provided practically all the flint blade material as in the Linear sites of the Moselle valley and Basse-Alsace. For the Moselle corridor Campanian and Maastricht flints from the Meuse (Limburg and Hesbaye) are the most plentiful up till 
the Late Linear followed by flints from the Paris Basin which replaced them in the last phases (mainly Senonian flints, Blouet 2005). A frontier exists between the Dutch flints (Rijckholt) and the flints from Belgium (Hesbaye Campanian) which distinguishes the north and south of the Moselle basin. In Basse-Alsace the flints from the Paris Basin and the North of the Jura make up the blade finds (Mauvilly 1997, 2000). This state of affairs has largely been confirmed by the recent excavations of the settlements - but also in the funerary field.

- In the Linear sites of the Aisne valley (from the Late Paris Basin Linear) a few pieces appear sporadically in exogenous materials, in Ghlin flint at Cuiry-lès-Chaudardes and also fine-grained Hesbaye flint at Missy-sur-Aisne and in a granular variety at Menneville (granular Hesbaye flint?). Ghlin flint - which is abundant in the Linear sites of the Hainaut in Belgium - is also found at Pont-Sainte-Maxence and Saint-Dizier in Champagne (one piece in each site). This last site has also yielded a small series of blades in fine-grained Hesbaye flint (Allard 2005). These few objects obviously had no economic impact, but their informative value is large since they are evidence of the existence of social relationships between the various zones of the Linear Ceramic.

The sites of the Seine/Yonne region are an interesting case in point. In this region rich in flint materials the series are significantly numerous (sometimes some tens of thousands of objects) and made from local or regional materials near at hand. Nonetheless, the presence of Tertiary flint from the centre of the Paris Basin is evidence of the circulation of a few pieces such as for instance piece 1 at Bréviandes or 1 at Etigny "le Brassot" (Augereau et al. 2006). It is therefore considered to be exogenous, although the distance from its sources is not necessarily greater than the normal regional supply. 
Acquiring materials is therefore quite a complex phenomenon in the Linear. The resources in flint were obviously not one of the criteria for choosing where to found settlements and several situations can be observed according to the availability and quality of the local and regional lithic resources. The findings observed in central Europe are entirely found again in the western margin of the Linear's area of expansion. Genuine circulation networks existed representing either contacts or economic relations between the production site and the consumer. This was borne out in Germany by the studies of A Zimmermann who also highlighted the competition between certain distribution networks (Zimmerman 1995).

The problem concerning the Paris Basin rested on recognising the various links in the distribution circuits - especially for the flints which may be considered to have had a heavy economic impact. This is the case for example for the Rijckholt flints from the Dutch Limburg or the Campanian Hesbaye flints of which the sites, with perfectly identified knapping workshops as at Verlaine, are known (Burnez-Lanotte and Allard 2004; Allard 2007; Burnez-Lanotte 2010), Beek (De Grooth 1987) or again very recently at Cannerberg (Amkreutz and van Wijk 2015).

Near to Troyes, the site of Bréviandes is a major discovery for a better understanding of the diffusion of upper Cretaceous blond flints. This site has yielded a very important quantity of lithic finds; 10 to 20 times more than had been known hitherto in the Linear sites in Champagne. The technological approach shows very clearly that all the stages in the chaine opératoire were present in the dwelling units in this site. From the initial pre-shaping to throwing away the core this settlement presents all the characteristics of a bladeproducing village. We are therefore in a position to propose a new comprehensive map showing the circulations of the materials, in which the site's location is quite significant 
since it is near the end-user settlements of Haute-Alsace for example. A type of upper Cretaceous blond flint from the Paris Basin is indeed well attested in the Alsatian series (Mauvilly 1997) or in Lorraine (Blouet 2005). This series is, to a certain extent, the missing link providing the proof of the presence in the Paris Basin of sites producing this flint, which was not the case with the very scanty assemblages from the Perthois - which in addition did not give this material pride of place. This flint network is the most important for the Linear in the Seine Bassin.

\section{Chronology of the circulation networks}

For the materials typical of the Paris Basin the chronology of the Cretaceous flints in the collections still has to be dated precisely for the earliest occupations of the Linear. Thus, pieces made from "upper Cretaceous flint from the Champagne plain" are found from the early phase of the Linear in Alsace (Mauvilly 1997: 333). They are, on the other hand, well attested from the middle phase of the Linear in the Moselle corridor and Alsatian plain. The site of Malling in Lorraine presents an assemblage including an important proportion of pieces in Cretaceous and Tertiary flint from the Paris Basin (Blouet 2005). In the Paris Basin the Middle Linear is very poorly documented and no reference set is known for the lithic finds.

In the late phase the networks became well established, and the circulations were dense and are very well documented (Fig. 1). The production site of Bréviandes is dated to this phase, just as are the sites with debitage heaps in Hesbaye and the Dutch Limburg. To us the late phase seems to have been the high point for blades produced for the circulation networks. In this phase a few Bartonian flint pieces have been found which circulated towards the south of the Paris Basin (Yonne, Aube). 
The final phase of the Linear shows a modification of the territory of supply as compared with the preceding phases in that the local materials became predominant at the expense of the regional materials (this fact is especially evident at the very end of the Linear). The circulation networks were still active and followed the same routes. At this period also the circulations between the sites in the Aisne/Oise valley and that of Saint Dizier with Belgium appeared. This concerns a few blades - Ghlin flint from the Hainaut and Hesbaye Campanian flint (Fig. 1b).

This period also witnessed the emergence of LPC sites in Normandy and raises the question of the possible circulations of the "Cinglais" flint. This good quality material, massively exploited for blade production in the Linear, may have been the subject of a genuine circulation network which we are unable to document in our current state of knowledge. New discoveries are needed but also the systematic search for this flint in the collections from the centre of the Paris Basin.

In the framework of a general synthesis the post-Linear is more delicate to describe as it is particularly poorly documented for the east of the Paris Basin (Champagne). In the Villeneuve-Saint-Germain a phenomenon of falling back on local raw materials occurred, but for all that the exchanges of raw materials did not disappear and continued to exist in ways that were still relatively complex. Generally, it is observed that the territory of supply in raw flint materials shrank in the Villeneuve-Saint-Germain to the materials available within a radius of 5 kilometres around the village. However, the presence of Cretaceous flint on the sites right in the heart of the Tertiary basin or of Bartonian flint in villages hundreds of kilometres from the core zone (Normandy, Belgium) is evidence of an occasional recourse to regional or exogenous materials. 
The Blicquy/Villeneuve Saint Germain culture is especially marked by a strong distribution network of Tertiary Bartonian flint (Bostyn 1994, 2008; Denis 2014). This material was exploited on production sites by experienced knappers and circulation routes similar to those found for the Linear reappeared. Thus, a few Bartonian pieces circulated towards the Seine/Yonne region, a few more towards Normandy, and a dense network developed with the sites of the Hainaut as far as Hesbaye in Belgium (Fig 1c).

The Jurassic flint called "Cinglais" was heavily exploited and regional networks developed (Charraud 2015), especially westwards, since this flint is found in the distant settlements in Brittany as for example at Betton and Saint Etienne en Cogles. The sector containing the "Cinglais" flint outcrops is where the first convincing vestiges of Late Neolithic mining activity have recently been found. There are two extraction sites with simple shafts that have yielded evidence of indirect percussion blade debitage at SoumontSaint-Quentin and Espins. The finds present the characteristics of Danubian debitage and two dates in shaft 26 of Espins indicate the beginning of the 5th millennium: 4997-4793 cal BC and 4930-4719 cal BC, i.e. the group of Blicquy/Villeneuve-Saint-Germain (Charraud 2015).

\section{Conclusion}

This assessment concerning the management of the territory of acquisition and the flint circulation networks for the Paris Basin highlights the intensity of the contacts between the various zones of settlement in the Linear culture's western area of expansion. With the recent discoveries it is really possible to talk in terms of networks in so far as the various links are now known for the Danubian period - from the flint's extraction site to its sites of production and consumption. The regular presence of a few exogenous pieces in the assemblages is also 
evidence of more discreet but still important contacts as they prove the existence of links with regions which are not always apparent in the other types of materials. Here we have only described the flint products but these kinds of circulations can also be observed for hard stones or for personal ornaments for example.

This management of materials is entirely in line with the founding and innovative research on the Linear Ceramic sites in central Europe conducted, in particular, by J. Lech who had demonstrated all the importance and organisation of the networks through which lithic products circulated (Lech 1987, 1990). These networks played a part in the functions of the society of the Linear culture and the relationships of which they are the sign are complex. For example, there is no correlation between the distance from the sources and the intensity of the circulations - as the circulation of Bartonian flint in the Paris Basin shows or the frontier effects that can be perceived. For the latter the Linear production sites are still to be discovered. The Blicquy/Villeneuve Saint Germain group reproduced communication routes that had been put in place in the Linear. Our knowledge has also increased now that the earliest flint mines have been found in Normandy - thereby also confirming the model for central Europe where these centres are disconnected from the settlements.

The next step necessary now would be to cross the whole material culture and comparer the circulation routes so as to have a clearer idea of the meaning of these links between the various zones of settlement for which we can sometimes see strong regional variations in the assemblages of finds. 
Alix, P., Arbogast, R.-M., Pinard, E. and Prodeo F. 1997. Le méandre de Pont-SainteMaxence (Oise) au Néolithique ancien. In : Le Néolithique danubien et ses marges entre Rhin et Seine. Actes du XXIIème colloque interrégional sur le Néolithique, 359-399, Strasbourg

Allard, P. 2003. Économie des matières premières des populations rubanées de la vallée de l'Aisne. In: Les matières premières lithiques en Préhistoire. Actes de la table ronde internationale d'Aurillac (Cantal), 20 - 22 juin 2002. Préhistoire du Sud-Ouest, sup. n`5, 1526, Cressensac

Allard, P. 2005. L'industrie lithique des populations rubanées du nord-est de la France et de la Belgique. Internationale Archäologie n ${ }^{\circ}$, Verlag Marie Leidorf GmbH, Rahden/Westf.

Allard, P. 2007. Surplus production of flint blades in the early Neolithic of Western Europe: new evidence from Belgium. European Journal of Archaeology, vol 8, 2005: 205- 223

Amkreutz, L. and van Wijk , I. 2015 'A day in the Life' - Cannerberg (the Netherlands), August 2nd 5045 cal BC. Analecta Praehistorica Leidensia 45: 173-179

Augereau, A., 2004. L'industrie du silex du Vè au Ivè millénaire avant J.-C. dans le sud-est du Bassin parisien. Documents d'Archéologie Française, 97, Ed. de la Maison des Sciences de l'Homme. Paris

Augereau, A., Creusillet, M.-F. and Meunier, K. 2006. Le site rubané d'Etigny “ Le BrassotEst" (Yonne). In : Duhamel P. (dir) - Impacts culturels au Néolithique moyen. Du terroir au territoire: sociétés et espaces. Actes du XXVe Colloque Interrégional sur le Néolithique, Dijon, 20-21 octobre 2001, 25e supplément de la Revue Archéologique de 1'Est, 261-286. Dijon

Augereau, A., Chambon, P. (dir.) 2011. Les occupations néolithiques de Macherin à Monéteau (Yonne). Mémoire de la Société Préhistorique Française n ${ }^{\circ 3}$. Paris

Billard, C., Bostyn, F., Hamon, C. and Meunier, K. (dir.) 2014. L'habitat du Néolithique ancien de Colombelles "Le Lazzaro " (Calvados). Mémoires de la Société préhistorique française $\mathrm{n}^{\circ} 58$. Paris

Blouet, V. 2005. L'industrie lithique du site Rubané moyen de Malling «le Domaine des Primevères» (Moselle). In G. Auxiette and F. Malrain (dir.), Hommages à Claudine Pommepuy, numéro spécial de la Revue Archéologique de Picardie n² 22, 29-38. Amiens

Blouet, V., Klag, T., Petitdidier, M.-P. and Thomashausen L. 2013. Le Néolithique ancien en Lorraine, Étude typochronologique de la céramique. Mémoires de la Société préhistorique française $n^{\circ} 55$. Paris

Bostyn, F. 1994. Caractérisation des productions et de la diffusion des industries lithiques du groupe néolithique du Villeneuve-Saint-Germain. Thèse de Doctorat, Université de Paris X

Bostyn, F. 2008. Les importations en silex bartonien du Bassin parisien sur les sites blicquiens en Hainaut belge. In L. Burnez-Lanotte, M. Ilett and P. Allard (dir.), Fin des traditions danubiennes dans le Néolithique du Bassin parisien (5100-4700 av. J.-C). Autour 
des recherches de Claude Constantin, mémoire XLIV de la Société Préhistorique Française, 397-412.

Boucneau, N., Bostyn, F. and Martinez, R. 1996. Chambly "le Clos de la Rivière" (Oise) - un site rubané récent très occidental. In P. Duhamel (dir.). La Bourgogne entre les bassins rhénan, rhodanien et parisien : carrefour ou frontière. Actes du 23ème colloque interrégional sur le Néolithique. Dijon, 1991, Revue Archéologique de l’Est, n¹4, 271-295. Dijon

Burnez-Lanotte, L. 2010. Acquérir, transformer, échanger ou consommer les matériaux siliceux au Rubané : problématiques et approche contextuelle du site de Verlaine "Petit Paradis" (Hesbaye, Belgique). Bulletin du Cercle archéologique Hesbaye-Condroz. XXX: 175-204.

Burnez-Lanotte, L. and Allard, P. 2004. Blade debitage in the Belgium Linearbandkeramik : the production at Harduémont 'Petit Paradis' (Verlaine). In L. Burnez-Lanotte (ed), Production and Management of lithic Materials in the European Linearbandkeramik UISPP, septembre 2001, Liège, Belgique. British Archaeological Reports, I.s. 1200: 59-64.

Cahen, D., Caspar, J.-P., Otte, M. 1986. Industries lithiques danubiennes de Belgique. Études et Recherches Archéologiques de l'Université de Liège n² 21. Liège

Charraud, F. 2015. Exploitation minière et gestion des lames en silex du Cinglais au Néolithique ancien : de la minière d'Espins (Calvados) « Foupendant » aux habitats du NordOuest de la France. Bulletin de la Société Préhistorique Française, T. 112 - Vol. 2: 317-338.

Constantin, C. 1985. Fin du Rubané, céramique du Limbourg et post-Rubané: le Néolithique le plus ancien en Bassin parisien et en Hainaut. British Archaeological Reports, International Series 273. Oxford

Dupont, F., Liagre J. and Irribarria, R. 2010. Sours «les Ouches» (Eure-et-Loir), un site original du Villeneuve-Saint-Germain ancien en région Centre. In C. Billard et M. Legris (dir.), Premiers Néolithiques de l'Ouest: cultures, réseaux, échanges des premières sociétés néolithiques à leur expansion dans l'Ouest de la France, actes du 28Colloque interrégional sur le Néolithique (Le Havre, 2007), Presses universitaires de Rennes, 75-100.

Farruggia, J.-P. 1971. Le Néolithique ancien dans le Bassin parisien - Aspects lithiques. Mémoire de Maîtrise, Université de Paris I.

Fournand, S., Allard, P., Bonnaire, E., Fechner, K., Hachem, L., Hamon, C., Maigrot, Y., Meunier, K. and Salavert, A. 2010. Un habitat rubané à Pont-sur-Seine/Marnay-sur-Seine (Aube). Interneo 8: 9-22.

Garmond, N., Binder, S., Bonnardin, S., Bouquin, D., Hamon, C., Lefevre, C. and Poupon, F. 2012. L'habitat rubané de Saint-Martin-sur-le-Pré «Rue des Castors» (Marne). Premiers résultats, Internéo 9: 35-47

Grooth, M.E.TH. (de) 1987. The organisation of flint tool manufacture in the dutch Bandkeramik. Analecta Praehistorica Leidensia, n²0: 27-52. 
Ilett, M. and Meunier, K. 2013. Avant-propos. In : K. Meunier and M. Ilett (dir.) Chronologie du Rubané dans le Bassin parisien. Séance de la Société préhistorique française du 10 juin 2011. Bulletin de la Société préhistorique française, T. 110, n³, 415-420. Paris.

Kaczanowska, M. and Lech, J. 1977. The flint industry of danubian communities north of the Carpathians. Acta Archaeologica Carpathica, tome XVII: 5-28.

Lefranc, P. 2007. La céramique du Rubané en Alsace: contribution à l'étude des groupes régionaux du Néolithique ancien dans la plaine du Rhin supérieur. Monographies d'Archéologie du Grand Est n². Strasbourg.

Laurelut, C. 2010. Bréviandes (Aube), un site danubien à forte composante non-rubanée dans la région de Troyes - Premiers éléments de réflexion. In C. Billard et M. Legris (dir.), Premiers Néolithiques de l'Ouest: cultures, réseaux, échanges des premières sociétés néolithiques à leur expansion dans l'Ouest de la France, actes du 28 Colloque interrégional sur le Néolithique (Le Havre, 2007), Presses universitaires de Rennes, 291-304.

Lech, J. 1980. Flint Mining among the Early Farming Communities of Central Europe. Przeglad Archeologiczny, n²8: 5-55.

Lech, J. 1987. Danubian raw matérial distribution patterns in earstern central Europe. In : Sievering G. de G. et Newcomer M.H. (eds.). The human uses of flint and chert. Cambridge, 241-248.

Lech, J. 1990. The organization of siliceous rock supplies to the danubian early farming communities (LBK) - central european examples. In : D. Cahen et M. Otte (éds.). Rubané et Cardial. Actes du Colloque de Liège, 1988. Études et Recherches Archéologiques de l’Université de Liège n³9, 51-59.

Marchand, G., Pailler, Y. and Tournay, G. 2006. Carrément à l'Ouest ! Indices du VilleneuveSaint-Germain au centre de la Bretagne (le Dillien à Cléguérec et bellevue à Neulliac ; Morbihan). Bulletin de la Société préhistorique française, vol. 103-3: 519-533

Mauger, M., 1985. Les matériaux siliceux utilisés au Paléolithique supérieur en Ile-deFrance. Thèse de Doctorat, Université de Paris I.

Mauvilly, M. 1997. L'industrie lithique de la culture à céramique linéaire de Haute et de Basse Alsace - état des recherches et bilan provisoire. Le Néolithique danubien et ses marges entre Rhin et Seine. Actes du XXIlème colloque interrégional sur le Néolithique. Strasbourg, 1995. 327-358.

Mauvilly, M. 2000. Le matériel lithique du site de Rosheim "Sainte-Odile" (Bas-Rhin). Première partie - objets en roches siliceuses et apparentées. Cahiers de l'Association pour la Promotion de la Recherche Archéologique en Alsace, tome 16: 67-81.

Meunier, K. 2012. Styles céramiques et néolithisation dans le Sud-Est du Bassin parisien. INRAP - CNRS Recherches archéologiques, 5. Paris.

Plateaux, M. 1982. L'industrie lithique du Rubané récent du Bassin parisien du site de Cuirylès-Chaudardes. Mémoire de maîtrise, Université Paris 1 - Panthéon-Sorbonne. 
Plateaux, M. 1986. L'industrie lithique des premiers agriculteurs dans le Nord de la France. Chipped stone industries of the early farming cultures in Europe. Actes du Colloque de Cracow, Archeologia interregionalis, 225-245.

Plateaux, M. 1990. Quelques données sur l'évolution des industries du néolithique danubien de la vallée de l'Aisne. In : D. Cahen et M. Otte (éds.). Rubané et Cardial. Actes du Colloque de Liège, 1988. Études et Recherches Archéologiques de l’Université de Liège n³9, 157-181.

Prost, D., Bedault, L., Biard, M. Dupont, C., Fromont, C. and Hamon, C. 2012. Le site du Néolithique ancien de Saint-Pierre-d'Autils (Haute-Normandie - Eure) : présentation liminaire. Internéo 9: 49-60.

Saint Allain, M. 2010. Démouville - ZAC du Clos neuf. Bilan scientifique de la BasseNormandie 2010, 51-53.

Tappret, É. and Villes, A. 1996. Contribution de la Champagne à l'étude du Néolithique ancien, in P. Duhamel (dir.), La Bourgogne entre les bassins rhénan, rhodanien et parisien : carrefour ou frontière?, actes du 18Colloque interrégional sur le Néolithique (Dijon, 25-27 octobre 1991), supplément à la Revue archéologique de 1'Est, 14, 175-256

Zimmermann, A. 1995. Austauschsysteme von Silexartefakten in der Bandkeramik Mitteleuropas. Universitätsforschungen zur prähistorischen archäologie Band 37, 162. Bonn. 

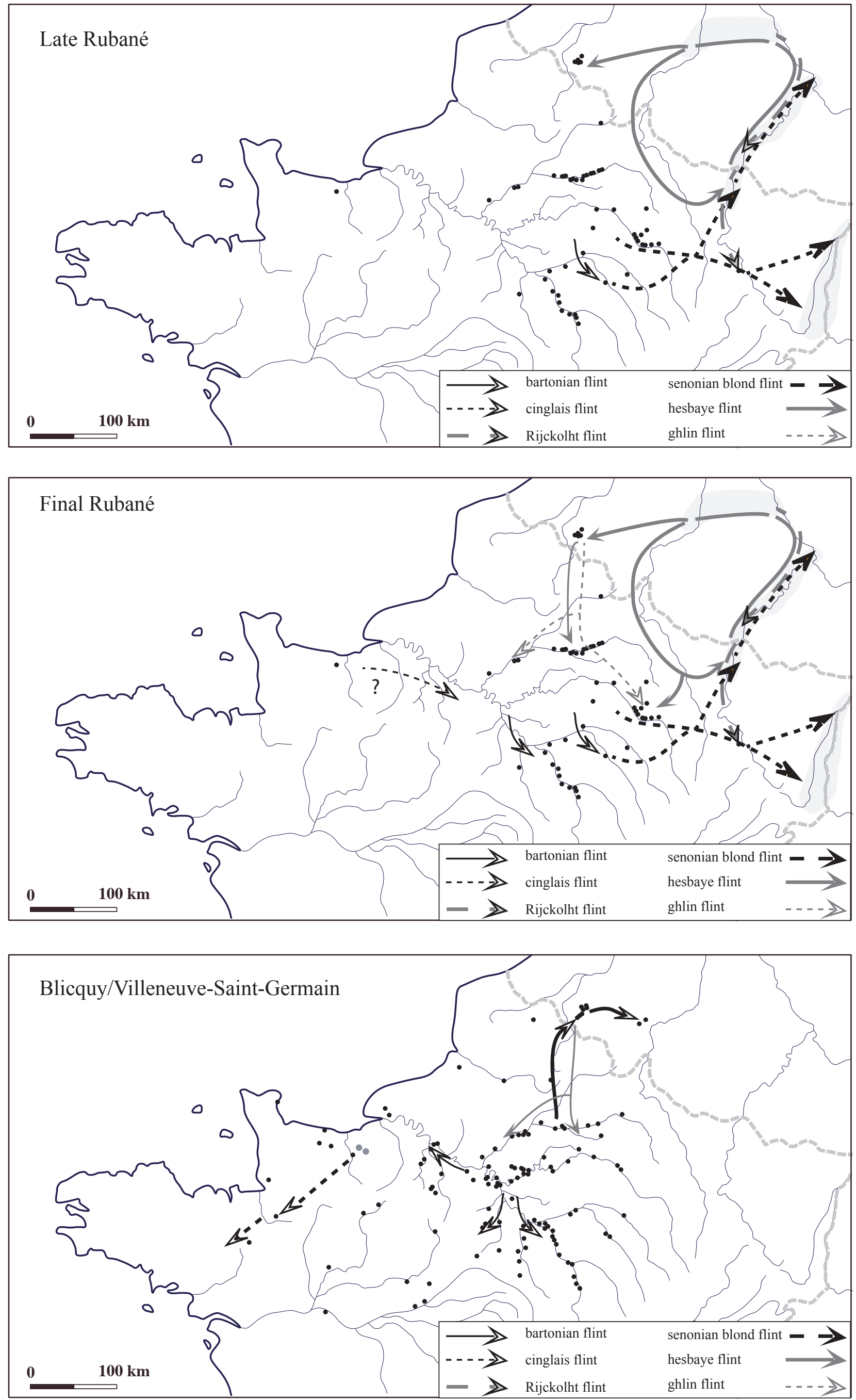